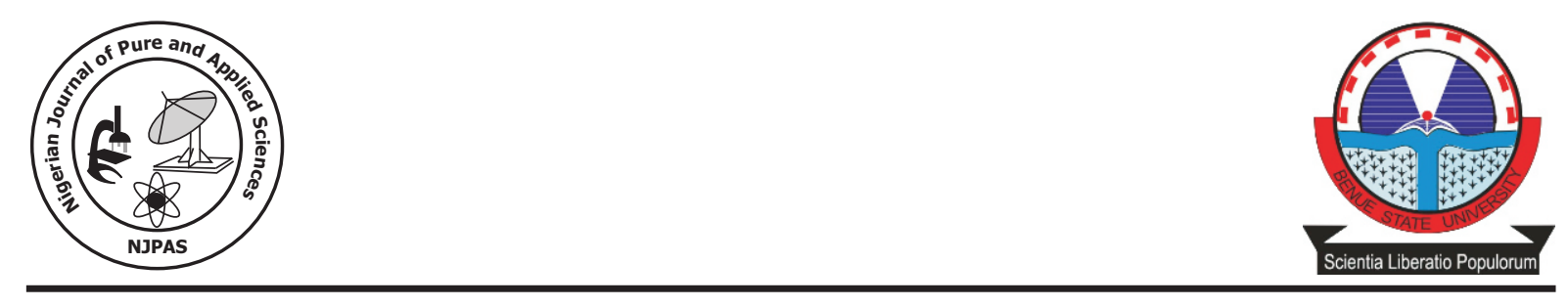

\title{
Antimicrobial and Bioactive Potentials of Extracts of Piliostigma thonningii Leaves
}

\author{
${ }^{1}$ Ipav, S. S., ${ }^{2}$ Dasofunjo, K., ${ }^{3}$ Sar, T. T. and ${ }^{1}$ Hilary, C. E. \\ 1.Department of Chemical Sciences, University of Mkar, Mkar, Benue State, Nigeria. \\ 2.Department of Medical Biochemistry, Cross River University of Technology, Okuku, Cross River. \\ 3.Department of Biological Sciences, University of Agriculture, Makurdi, Benue State, Nigeria \\ Email; selumunipav@gmail.comTel; +234 8036487889
}

\begin{abstract}
The aqueous, ethanolic and petroleum ether extracts of Piliostigma thonningii Fabaceae (Leguminasae) - Caesalpinioidae were tested for bioactive and antimicrobial activities against Staphylococcus aureus (Gram-positive), Escherichia coli and Klebsiella pneumoniae (Gram-negative) and Candida albicans (fungus). The ethanolic extracts inhibited the growth of the pathogenic organisms with zones of inhibition ranging from $6.40 \pm 0.42 \mathrm{~mm}$ to $10.0 \pm 0.22 \mathrm{~mm}$ while the aqueous and petroleum ether extracts seem to be ineffective. The leaves of Piliostigma thonningii have high concentrations of flavonoids, tannins, steroids, phlobatannins, saponins, terpenoids, cardiac glycosides and alkaloids. The ability of the ethanolic extract of the leaves to inhibit the growth of the test bacteria and fungus is an indication of its antimicrobial potency which may be employed in the treatment of microbial infections and degenerative diseases.
\end{abstract}

Keywords: Antimicrobial activity, degenerative diseases, Phytochemical Screening, Piliostigma thonningii.

\section{Introduction}

African plants have long been the source of important products with nutritional and medicinal potentials. Some of these potentials might be attributed to the bioactive constituents (phytoconstituents) of these plants. An important plant with medicinal potentials is Piliostigma thonningii. Piliostigma thonningii belongs to the family Fabaceae (Leguminasae) - Caesalpinioidae comprising of trees, shrubs or very rarely scramblers (Thompson, 2010). It was previously known as Bauhinia thonningii but later differentiated by its unisexual flowers and indehiscent pods with rusty brown hairs which wear off as the pods mature, becoming somewhat contorted as they age (Thompson,
2010; Djuma, 2003).

In Nigeria, the plant is found growing abundantly as a wild uncultivated tree in many locations such as Ogun, Bauchi, Kwara, Lagos (Jimoh and Oladiji, 2005) and some parts of Kogi, Benue and Nasarawa States. Its local names include Abefe in Yoruba, Kalgo in Hausa, Okpoatu in Igbo (Jimoh and Oladiji, 2005; Rabo and Sanusi, 2001; Odukoya, 2002; Igoli et al, 2003; Molta et al, 2004; Edeoga et al, 2005; Aderogba et al, 2006; Brummit et al, 2007; Sofowora, 1993; Ozolua et al, 2009), Nyihar in Tiv and Ejei-jei in Igala languages of Nigeria. In Africa, Piliostigma thonningii is one of the plants with diverse ethno-medical and economic applications (Igoli et al, 2003). The medicinal value of 
different parts of the plant has been examined, of which various preparations of its parts have been used to arrest bleeding, treat fevers and bacterial infections; as laxative, as antihelminthic and anti-inflammatory agents (Igoli et al, 2003; Fakae et al, 2000; Togola et al, 2005). Other acclaimed medicinal roles include antioxidant, anticancer, anticough and aphrodisiac potentials. Due to its potentials, this research was carried out to determine the antimicrobial activity and bioactive components of Piliostigma thonningii.

\section{Materials and Methods \\ Plant Material}

Fresh leaves of Piliostigma thonningii were collected from Mkar Hills in Gboko. Gboko is found in Benue state, North Central Nigeria and is situated on longitude $9^{\circ} \mathrm{E}$ and latitude $7.0^{\circ} \mathrm{N}$ and $7.50^{\circ} \mathrm{N}$. The leaves were identified at the Federal College of Forestry (FCOFJ) Jos, and given a voucher number of \#25.

\section{Preparation of Plant Material}

Fresh leaves of Piliostigma thonningii were collected and air dried for 14 days until constant weight was obtained. They were pulverized using a blender machine and sieved to obtain the powdered form. About $300 \mathrm{~g}$ each of the powder was dissolved in $1000 \mathrm{ml}$ of aqueous, ethanol, petroleum ether as solvent, respectively, for 72 hours to achieve maximum extraction for phytochemical screening and antimicrobial potential.

Each of the solution was filtered using what-man No.1 filter paper and the filtrate were concentrated in water bath at $50^{\circ} \mathrm{C}$.

\section{Phytochemical Screening}

The phytochemicals (flavonoids, tannins, steroids, phlobatannins, saponins, terpenoids, glycosides and alkaloids) were tested for, using the methods of Trease and Evans (1989) and modified by Sofowora (1993) and Harbone (1996).

\section{Antimicrobial Potential of $P$. Thonningii Leaves Extracts \\ Microorganisms}

The antibacterial activity of the aqueous, petroleum ether and ethanol extracts was tested individually on Gram-positive and Gram-negative bacterial strains and yeast. All bacterial strains and yeast were obtained from Microbiology Department, National Hospital, Abuja, Nigeria. These test organisms include: Staphylococcus aureus (ATCC 25923) (Gram-positive), Escherichia coli (ATCC 25923) and Klebsiella pneumoniae (ATCC 70063) (Gram-negative) and Candida albicans (fungus). The antibacterial activity of the aqueous, petroleum ether and ethanol extracts was tested individually on Grampositive and Gram-negative bacterial strains and yeast. Twenty-four, $0.1 \mathrm{ml}$ nutrient broth, $37^{\circ} \mathrm{C}$ incubated suspension of the bacterial isolates were sub-cultured onto nutrient Agar plates in and evenly spread in a uniform lawn. In the case of C. albicans, a 48 hour, $0.1 \mathrm{ml}$ sabourand broth suspension, incubated at $37^{\circ} \mathrm{C}$, was sub-cultured onto sabourand Dextrose medium. $25 \mathrm{ml}$ of all sub-cultured media per petri plate were used (Ochei and Kolhatkar, 2000).

\section{Agar Disc Diffusion Assay}

The antibacterial activity of the extracts were determined by the disc diffusion method of Rios et al, (1998). Four filter paper discs (Whatman No1, $6 \mathrm{~mm}$ diameter) were placed on the innoculated agar surface. A $20 \mu 1$ $(100 \mathrm{mg} / \mathrm{ml})$ of each of the extracts were loaded on to the filter paper discs and were allowed to be air dried completely. Standard antibiotics: ampicillin $(10 \mu \mathrm{g})$, gentamicin $(10 \mu \mathrm{g})$ and $20 \mu \mathrm{l}$ of DMSO (dimethylsulphoxide) were placed as controls. Plates were incubated at $37^{\circ} \mathrm{C}$ for 24 hours after the extracts-impregnated discs were introduced on the agar. Antimicrobial activity was assessed by measuring the inhibition zone. All the tests were performed in triplicates.

The minimum inhibitory concentration (MIC) and the minimum bactericidal concentration (MBC) were determined using 
Rios et al (1998) method as modified by Cutler et al (1994) and Kone et al (2004).

\section{Statistical Analysis}

Data were presented as mean \pm SD of five determinations. Statistical analyses were carried out using one way analysis of variance (ANOVA). Differences were statistically significant at $\mathrm{P}<0.05$

Results:

The preliminary phytochemical analysis revealed the presence of flavonoids, tannins, steroids, phlobatannins, saponins, terpenoids, glycosides and alkaloids in aqueous, petroleum ether and ethanolic extracts respectively (Table 1).

Table 1: The Phytochemical Composition of Aqueous, Petroleum ether and Ethanolic Extracts of $P$. thonningii Leaf.

\begin{tabular}{llll}
\hline Phytochemicals & Aqueous Extract & Petroleum ether Extracts & Ethanol Extract \\
\hline Flavonoids & ++ & + & +++ \\
Tannins & + & +++ & ++ \\
Steroids & ++ & ++ & +++ \\
Phlobatannins & ++ & ++ & +++ \\
Saponins & ++ & + & ++ \\
Triterpenoids & ++ & ++++ & +++ \\
Glycosides & ++ & +++ & +++ \\
Alkaloids & + & ++ & +++ \\
\hline
\end{tabular}

Where: $+=$ sparingly present

$++=$ moderately present

$+++=$ highly present

$++++=$ very highly present

\section{Antimicrobial Activity of the Extracts}

Table 2 depicts the antimicrobial potential of the aqueous, petroleum ether and ethanolic extracts of the $P$. thonningii leaf. Though the effect of the extract on the entire organism was not significant $(\mathrm{P}>0.05)$, differences exist when compared individually.

Zones of inhibitions were wider at $100 \mathrm{mg} / \mathrm{ml}$ with ethanolic extract than aqueous and petroleum ether extracts. This showed that ethanol extract inhibited the growth of Staphylococcus aureus, Escherichia coli, Klebsiella pneumonia and Candida albicans with zones of $8.80 \pm 0.24 \mathrm{~mm}, 7.60 \pm 0.32 \mathrm{~mm}$, $10.0 \pm 0.22 \mathrm{~mm}$ and $6.40 \pm 0.42 \mathrm{~mm}$ respectively; while aqueous and petroleum ether extracts were ineffective against these microbial strains. The reason for this occurrence is presently unknown.

Table 2: Zones of microbial inhibitions by aqueous, petroleum ether and ethanol extracts of P. thonningii Leaf at $100 \mathrm{mg} / \mathrm{ml}$.

\begin{tabular}{llll}
\hline Organisms & $\begin{array}{l}\text { Aqueous Extract } \\
\mathbf{1 0 0} \mathbf{m g} / \mathbf{m l}\end{array}$ & $\begin{array}{l}\text { Petroleum ether } \\
\text { Extract } \\
\mathbf{1 0 0} \mathbf{m g} / \mathbf{m l}\end{array}$ & $\begin{array}{l}\text { Ethanol Extract } \\
\mathbf{1 0 0} \mathbf{m g} / \mathbf{m l}\end{array}$ \\
\hline Staphylococcus aureus & - & $2.9 \pm 0.20 \mathrm{~mm}$ & $8.8 \pm 0.24 \mathrm{~mm}$ \\
Escherichia coli & $1.0 \pm 0.21 \mathrm{~mm}$ & $1.6 \pm 0.32 \mathrm{~mm}$ & $7.6 \pm 0.32 \mathrm{~mm}$ \\
Klebsiella pneumonia & $0.0 \pm 0.22 \mathrm{~mm}$ & $1.3 \pm 0.12 \mathrm{~mm}$ & $10.0 \pm 0.22 \mathrm{~mm}$ \\
Candida albicans & $0.0 \pm 0.00 \mathrm{~mm}$ & $2.0 \pm 0.23 \mathrm{~mm}$ & $6.4 \pm 0.42 \mathrm{~mm}$ \\
\hline
\end{tabular}

\section{Discussion}

Methods of extraction can affect the physical properties of the extracts, especially its solubility in solvents (Kone et al, 2004). It has been shown that solvent to be used in the reconstitution of the extract should be considered before adopting a particular extraction method as it could affect the solubility of the extract in a solvent (Wang and Weller, 2006). 
In general, the ethanol extract of the plant was most effective in inhibiting the microbial growth suggesting that polar solvent ethanol was most successful in extracting secondary metabolites responsible for the antimicrobial property than aqueous and petroleum ether solvents.

The presence of the bioactive compounds in crude extracts is known to confer antimicrobial activity against disease -causing microorganisms (pathogens) and offer protection to plants themselves against pathogenic microbial infections (Hanmougjai et al, 2000; Farnsworth, 1982). Bioactive secondary metabolites have been utilized as natural medicines and plants containing those compounds that have been used as medicinal plants are prescribed in many recipes as forms of crude drugs (De and Ifeoma, 2002).

It was observed that the zones of inhibition in these extracts were generally narrow compared to the control, this could be due to the prolonged effect of heat on the extract (during extraction) that inactivated some active thermolabile components (Chattopadhyay et al, 2007).

The presence of phytocompounds, suggest their usefulness in folk medicine (Luque-Garcia and Luque De Castro, 2004). Flavonoids have been shown to have antibacterial, anti-inflammatory, anti-allergic, anti-neoplastic, antiviral, anti-thrombotic and vasodilatory activities (Luque-Garcia and Luque De Castro, 2004; Zuin and Vilegas, 2002). Many of the alleged functions of flavonoids have been linked to their known functions as strong antioxidant, free radicals scavengers and metal chelators (Zuin and Vilegas, 2002; Miller, 1996). Flavonoids have been referred to as nature's biological response modifiers because of strong experimental evidence of their inherent ability to modify the body's reaction to allergen, virus and carcinogens. They show anti-allergic, anti-inflammatory, anti-microbial and anticancer activities. Some flavonoids have also been reported to behave like some coumarins in the inhibition of giant cell formation in HIVinfected cell culture (Ayoola et al, 2008).
The presence of flavonoids in all the extracts suggests $P$. thonningii is a powerful antioxidant phenolic compound which can inhibit the formation of superoxide ions and hydroxyl radicals which are strong peroxidation agent. Hence, revealing the mystery behind its continual usage in folk medicine.

Flavonoids and or Saponin constituents of plant have been reported to alter androgen levels (Raj and Shalini, 1999). Saponins from plants have long been employed for their detergent properties. It is used as mild detergents and in intracellular histochemistry staining to allow antibody access to intracellular proteins. In medicine, it is used as hypercholesterolemia, hyperglycaemia, antioxidant, anti-cancer, anti-inflammatory and weight loss (Zuin and Vilegas, 2002). Seigler (1998) reported that saponnins have anti-carcinogeneous properties, immune modulatory activity and cholesterol lowering activity. It is also been reported to have antifungal properties (Ngbede et al, 2008). Some saponins glycosides are cardiotonics, while others are contraceptives and precursors for other sex hormones (Ayoola et al, 2008). Steroids increase nitrogen levels in the body, thereby producing proteins that help in the production of muscles, improve penile blood flow and thereby ameliorating erectile dysfunctional challenges. Steroids could also enhance metabolism and thus inhibit the accumulation of fat to correct such disorders like anemia by increasing the production of red blood cells in the body and contribute to the treatment of arthritis, asthma, brain injury and some types of cancer. However, steroids could enhance the onset and progression of cardiovascular and liver diseases as well as acne (by stimulating the sebum to produce oil. The presence of steroids in the extracts suggests its erythropoietic, hepatoprotective, hypolipidemic and aphrodisiac potency of the extracts of Piliostigma thonningii leaf. Cardiac glycosides are known to work by inhibiting the $\mathrm{Na}^{+} / \mathrm{K}^{+}$pump. This cause an increase in the level of sodium ions in the myocytes and then led to a rise in the level of $\mathrm{Ca}^{2+}$. This inhibition increases the amount of 
$\mathrm{Ca}^{2+}$ ions available for contraction of the heart muscle which improves cardiac output and reduces distention of heart; thus are used in the treatment of congestive heart failure and cardiac arrhythmia (Zuin and Vilegas, 2002; Seigler, 1998). Therefore, the presence of cardioglycosides in the extracts may pose a further research on heart related challenges. Tannins sacs are known to be common in Caesalpinoideae and known to exhibit antiviral, antibacterial and anti-tumor activities. It was also reported that certain tannins are able to inhibit HIV replication selectively and is also used as diuretic. Plant tannins are also source of commercial tannic acids and tanning agents (Ayoola et al, 2008).

Therefore, it will be logical to conclude that the acclaimed folkloric aphrodisiac, anti malarial, anti inflammatory, anticancer and other therapeutic potentials of $P$. thonningii might be due to the bioactive constituents in the plant. These bioactive constituents (phytochemicals) are known to be responsible for inhibition of some microbial growth, which suggests its potency also in the management of pathogenic microbial infections.

\section{References}

Aderogba, M.A., Okoh, E.K., Okeke, I.N., Olajide, A.O. and Ogundaini, A.O. (2006). Antimicrobial and anti inflammatory effects of Piliostigma reticulatum leaf extract. International Journal of Pharmacology 2(1): 70-74.

Ayoola, G. A., Ipav, S. S., Sofidiya, M.O., Adepoju-Bello, A. A., Coker, H.A.B and Odugbemi, T.O (2008). Phytochemical Screening and Free Radical Scavenging Activities of the Fruits and Leaves of Allanblackia floribunda Oliv (Guttiferae). International Journal of Health Research, 1(2);87-93.

Brummitt, R.K., Chikuni, A.C., Lock, J.M. and Polhill R.M. (2007). Leguminosae, sub family Caesalpinioideae. In:Timberlake, J.R., Pope, G.V., Polhill, R.M. \& Martins, E.S.(Editors). Flora Zambesiaca. Volume 3, part 2. Royal Botanic Gardens, Kew, Richmond, United Kingdom. p218.
Chattopadhyay, R. R., Bhattacharyya, S. K., Medda, C., Chanda, S., Datta, S and Pal, N. K (2007). Antibacterial activity of black myrobalan (Fruit of Terminalia chebula Retz.) againstpathogen Escherichia coli: Phcog. Mag.11:212-5.

Cutler N.R.C., Sramek, J. S. and Prem, K.N. (1994). Pharmacodynamics and drug development: Perspectives in clinical pharmacology. New York: John Wiley and Sons; 1994. p.318.

De, $\mathrm{N}$ and Ifeoma, E (2002). Antimicrobial effects of components of the bark extract of neem Azadirachta indica A. Juss Technol Dev: 8:23-8.

Djuma (2003). Djuma Game Reserve Copyright $(\mathrm{C}$ 1998-2003.

Edeoga, H.O., Okwu, D.E. and Mbaebe, B.O. (2005). Phytochemical constituents of some Nigerian medicinal plants. Afr. $J$. Biotechnol. 4(7): 685.

Fakae, B.B., Cambell, A.M., Barrett, J., Scott, I.M., Teesdale-Spittle, P.H., Liebau, E. and Brophy, P.M. (2000). Inhibition of gluthathione S-transferase(GSTs) from parasitic nematodes by extracts from traditional Nigerian medicinal plants. Phytother. Res. 14: 630-634.

Farnsworth, A.C. (1982). The role of ethnopharmacology drug development from plants: England Ciba:John Wiley and Sons. p. 2-10.

Hanmougjai, P., Pyle, L and Niranjan, K (2000). Extraction of rice bran oil using aqueous media: J.Chemical Technol. And Biotechnol., 75: 348-352.

Harborne, J. B. (1996). Phytochemical methods. London: Chapman and Hall Ltd. Pp. 52-105.

Igoli, J.O., Igwue I.C. and Igoli N.P.(2003). Traditional medicinal practices among the Igede people of Nigeria. Journal of Herbs, Spices and Medicinal Plants 10(4): 1-10.

Jimoh F. O. and Oladiji A. T. (2005). Preliminary studies on Piliostigma thonningii seeds: Preliminary analysis, mineral composition 
and phytochemical screening. Afr. J. Biotechnol., 4:1439-1442.

Kone, W. M., Kamanzi, A. K., Terreaux, C., Hostettmann, K., Traore, D and Dosso, M. (2004).Traditional medicine in North Coted'Ivoire: screening of 50 medicinal plants for antibacterial activity. J. Ethno. pharmacol. 93:43-9.

Luque-Garcia, J. L and Luque De Castro, M. D. (2004). Ultrasound - assisted Soxhlet extraction: An expeditive approach for solid sample treatment- Application to the extraction of total fat from oleaginous seeds. J. Chromatography A.,1034: 237242.

Miller, A.L (1996). Antioxidant Flavonoids: Structure, Function and Clinical Usage. Alt. Med. Rev.;1(2): 103-111.

Molta, N.B., Watila, I.M. and Oguche, S. (2004). Responses of Plasmodium falciparum infections to anti malarial drugs in north eastern Nigeria part1: 1988-1995.J. Pharm. Bioresour. 1(1):51-60.

Ngbede, J., Yakubu, R.A and Nyam, D. A (2008). Phytochemical Screening for Active Compounds in Canarium schweinfurthil (Atile) leaves from Jos North, Plateau State Nigeria. Medwell Research Journal of Biological Science, 3(9):1076-1078.

Ochei, J and Kolhatkar, A (2000). Medical Laboratory Science Theory and Practice. New Delhi, Tata McGrawhill Publishing Company Limited. p1338.

Odukoya O. A. (2002). Herbs, Species and Medicinal Plants. Nig. J. Pharm. Res. 1: 3940 .

Ozolua, R.I., Alonge, P., and Igbe, I. (2009). Effects of leaf extracts of Piliostigma thonningii Schum on aortic ring contractility and bleeding time in rats. Journal of Herbs, Spices and Medicinal Plants 15(4):326-333.
Rabo E.T.and Sanusi S.S. (2001). An inventory of medicinal plants of the Nigerian Savannah: Leviathan books, Lagos, Nigeria. pp. 21-24.

Raj, K.J and Shalini (1999). Flavonoids- a review of biological activities. India Drugs, 36:668-676.

Rios, J. L., Recio, M. C and Villar, A. (1988). Screening methods for natural products with antimicrobial activity: A review of the literature. J. Ethnopharmacol. 23:127-149.

Seigler, D. S (1998). Plants with saponins and cardiac glycosides: www.lifwe. vinc.edu/plantbio/363/saponinslides

Sofowora, A. (1993). Medicinal Plants and Traditional Medicine in Africa: 3rd ed., Spectrum Books Limited Ibadan, Nigeria, pp: 199-204.

Thompson M. (2010). Piliostigma thonningii: Walter Sisulu National Botanical Garden November 2010; The South African National Biodiversity Institute's plant i n f o r m a t i o $n \quad$ w e b s i t e www.plantzafrica.com.

Togola, A., Diallo, D., Dembele, S., Barsett, H and $\mathrm{P}$ a u $1 \mathrm{~s}$ e $\mathrm{n}, \mathrm{B} . \mathrm{S}$. ( ( $\left.\begin{array}{llll}2 & 0 & 0 & 5\end{array}\right)$. Ethnopharmacological survey of different uses of seven medicinal plants from Mali, (West Africa) in the regions Doila, Kolokani and Siby. J. Ethnobiol. Ethnomed., 1:7.

Trease, A. and Evans, W. C. (1989). Pharmacognosy: $13^{\text {th }}$ ed. London, Bailiere Tindall. Pp. 342-383.

Wang, L and Weller, C. L (2006). Recent Advances in extraction of Nutraceuticals from plants. Trend in Food Science and Technology (Elsevier), 17: 300-312.

Zuin, V.G and Vilegas, J.H (2002). Pesticide residue in medicinal plants and phytomedicines. Phytother Res.14:73-88. 